\title{
Defining Minorities: Mission Impossible? The Case of Hashemite Iraq
}

\section{Aline Schlaepfer, Department of Arabic Studies, University of Geneva, aline.schlaepfer@unige.ch}

After the collapse of the Ottoman Empire, a new order came to light in the Arab Middle East, based on the dissolution of the empire on the one hand, and the emergence of states meant to represent the people around a common history, culture, and territory, on the other hand. In all plural societies of the region, the concepts of "majority" and "minority" became instrumental in defining political representation. Accordingly, a series of postwar treaties and declarations intended to protect minorities were established, under the auspices of the League of Nations. In the post-Ottoman context, while the concepts of millet and ta ifet were eventually replaced by that of "minorities" at different stages of the 20th century, the process was neither natural nor unanimous. This contribution seeks to examine the process by which various nondominant groups in newly-created Hashemite Iraq responded to the new order, with a focus on the minoritization of the Jewish community.

To start with, defining a minority and its function in society-whatever the political context-is an intricate task. An impossible mission, some might even $\operatorname{argue}^{1}$, because the categories are far from obvious. In Iraq, what did it technically mean to be part of the majority? Was the majority Muslim (that is neither Christian nor Jewish), or was it based on fluency in Arabic (and thus not Kurdish, Turkish, or Aramaic)? Did it mean being an Iraqi national (and therefore not Persian)? And, even more problematic in terms of political representation, was the distinction based on Sunni and Shi'i identity. As Peter Sluglett has noted, the Sunnis in Iraq acted as a "minoritywhich-behaves-as-if-it-were-a-majority."2 The case of political domination by a numerical 
minority (Sunnis) over the numerical majority (Shi'a), is in this respect comparable to the situation in the Gulf in particular, and others around the globe in general ${ }^{3}$.

Between August and September 1932, the "Committee for the defense of the rights of the Iraqi nation" addressed a series of petitions to the Permanent Mandates Commission of the League (PMC) challenging the definition of a "minority." In the case of the Shi 'ia in Iraq, they argued, a "crowned minority" of Sunnis - a reference to Faysal and his entourage - was ruling over an oppressed majority of Shi'a. The Sunnis, therefore, did not need protection. An inquiry was initiated, but the demands were rejected on the basis that they were anonymous. ${ }^{4}$

The complex phenomenon of transition from millet to minority has been the focus of numerous historical studies. ${ }^{5}$ To the question of what remains of the millet system after the collapse of the Ottoman Empire, answers are many. Some have emphasized continuity, arguing in terms of a "neo-Millet partnership" 6 between the church and the state in the case of Egypt, for example, and others have focused on the impact of rupture and the subsequent implementation of minorities ${ }^{7}$. All in all, political practices within various groups could most adequately be described as hybrid. In Iraqi constitutional history, this hybridity is particularly salient. Charles Arthur Hooper, a lawyer at the British embassy in Baghdad in the early 1920s and one of the main observers of the drafting for the Iraqi Organic Law of 1925, wrote a long memorandum submitted to the Colonial Office in December 1927 "explaining to what extent the Turkish Law is still in force in Iraq." With regards to the articles concerned with Jews and Christians, we know that representatives of both communities were consulted at different stages of the drafting, in particular regarding judicial articles. ${ }^{9}$ Eventually, two different words were used to refer to Jews and Christians in the Organic Law of 1925: aqalliyya for "minority" appears once, and ta 'ifa for community, a 
heritage from the Ottoman millet, was used nine times. ${ }^{10}$ "Never total change, never total continuity."11

However, by the time the Constitution was put into effect in the mid-1920s, the question of minorities was still not yet settled. The Anglo-Iraqi Treaty of 1930 did not provide special measures for the Kurdish provinces, to begin with. In fact, discussions on the definition of racial, religious, and linguistic identities intensified at the turn of the 1930s around two main concerns; the question of the independence of Iraq, and the necessity for the Iraqi government to draft a declaration regarding the protection of minorities, approved in May 1932. The impact of the tensions between the League members and Britain regarding independence discussed in length by Susan Pedersen, is crucial to understanding the process of minoritization in Iraq. While British officials pressured the PMC to accept the proposition for Iraqi independence, the latter was openly hostile to the decision. From the perspective of the British, Pedersen shows, the proposition for independence was not intended as a helping hand offered to the Iraqis. Rather, it was part of a strategy of influence to maintain "a low-cost hegemonic position in Iraq," outside of the League's grip. ${ }^{12}$

Amid these heated debates in Iraq, in the early 1930s, it was clear to the groups in the position of claiming more guarantees of protection, that these requests became synonymous with rejection—or at least delaying—independence. Put differently, it could be taken as a sign of disloyalty towards the Iraqi Hashemite state. In one of the many British reports on the conditions of minorities in Iraq at the time of independence, the Foreign Office expressed fear that "the great danger to the minorities, if too elaborate arrangements were made to place them under League protection, was that they might be regarded as the outposts of foreign intervention."13 Accordingly, the nature of these groups' responses to their minoritization arguably reflects more 
on the perceived threat of this accusation than on a genuine perception of themselves as a minority.

With regards to the groups in Iraq considered minorities by the international community (primarily Jews and Christians, but also Baha'is, Turkmens, Kurds, and Yezidis, depending on the context), their minority status was widely discussed on the eve of independence, including by representatives and various actors from these groups. In terms of the Jews, their representatives, as Helen Müller-Sommerfeld has argued, officially rejected the status of minority. ${ }^{14}$ The statement by the Jewish Minister of Finance in Iraq Sasun Hasqayl, while in Geneva in December 1931, expressed the fears of some Jews of being considered non-Iraqis if they were to be labeled "minority": "When the question of guarding the rights of minorities in 'Iraq was raised Sir Sassoon Heskel on behalf of the 'Iraqi Jewry declared at Geneva that the Jews regard themselves as 'Iraqis and do not claim any minority rights." ${ }^{15}$ Similarly, when the legal status of the Jewish community was regulated in 1931 by the Israelite Community Law (Qanun al-Ta' ifa alIsra' iliyya) the word "minority" (aqalliyya) appeared nowhere. ${ }^{16}$ As for British official documents about the Jews at this specific time of history, they tended to insist that Jews enjoyed freedom and prosperity, lived on good terms with Muslims, and therefore needed not be a protected minority: "(They) are the most prosperous community in 'Iraq." ${ }^{17}$ But in the light of British continued pressure to silence minority claims, these descriptions of Iraqi Jews in a favorable light should be approached with caution.

In a letter addressed to the League's Minorities Section in December 1931, the secretary of the Jewish association Joint Foreign Committee J. Rich, explains his decision to support the termination of the Mandate: "Subsequent to my return to London, my Committee received further reports on the subject, and satisfied itself that the Jews of Iraq did not desire that any obstacles of 
any nature should be placed in the way of the termination of the Mandate. My Committee ... has accordingly taken no steps to bring before the League the special considerations relative to the Jewish Minority in Iraq which it had in mind."18 The details of the decision suggest that concerns regarding the status of Jews had previously been voiced among certain parts of the Jewish community, for which Rich and his committee had initially supported claims for minority rights. His meetings in London, however, convinced him to change his mind. In other words, Iraqi Jewish responses to their own minoritization were not unanimous and the choice of their representatives to reject it resulted from a diplomatic strategy that was arguably not unanimously supported by all Iraqi Jews.

In conclusion, to follow up on Heather Sharkey's contribution to this roundtable, Iraqi Jews offer just one example of minorities' responses. One could also look at other nondominant groups, such as the Kurds, the Assyrians, the Yezidis, the Baha'is, or others, and examine in more details the ways in which these groups responded to their own minoritization on the eve of independence. After all, minoritization, in the context of our discussion, is not a homogenous, natural, and continuous process that can be applied to all nondominant groups in similar ways. Minoritization is a series of moments, often moments of crises, with their own logic, contingency, causes, and consequences ${ }^{19}$. The Iraqi independence of 1932 is one of these moments, yet there are many others left to study.

\footnotetext{
1 “Les minorités : l'impossible définition en droit international". Alain Fenet, Geneviève Koubi, and Isabelle Schulte-Tenckhoff, eds., Le droit et les minorités: analyses et textes (Bruxelles: E.
} 
Bruylant, 2000 (1995)), 18-24; François Rigaux, "Mission impossible: la définition de la minorité," Revue trimestrielle des droits de l'homme 30 (1997) : 155-175.

2 Peter Sluglett, "From Millet to Minority. Another Look at the Non-Muslim Communities in the Late Nineteenth and Early Twentieth Centuries," in Minorities and the Modern Arab World: New Perspectives, ed. Laura Robson, (Syracuse: Syracuse University Press, 2016), 19-38, here 19.

${ }^{3}$ Claire Beaugrand, "Deconstructing Minorities/Majorities in Parliamentary Gulf States (Kuwait and Bahrain)," British Journal of Middle Eastern Studies 43, vol. 2 (2016): 234-249.

${ }^{4}$ P. Anker to Vito Catastini, 10 October 1932. Vito Catastini to Alberto Theodoli, Geneva, 10 October 1932. Theodoli to Catastini, Rome, 26 October 1932. Le Comité central de la Défanse (sic) des Droits de la nation iraquienne, "La voix étouffée d'Irak," Baghdad, August 1932 (LN, R2176/4/35957).

${ }^{5}$ For a discussion on the emergence of the concept of minorities, consider for instance Benjamin Thomas White, The Emergence of Minorities in the Middle East (Edinburgh: Edinburgh University Press, 2011); Seteney Shami, “Aqalliyya/Minority in Modern Egyptian Discourse," in Words in Motion: Toward a Global Lexicon, ed. Carol Gluck and Anna Lowenhaupt Tsing, (Durham: Duke University Press, 2009), 151-173; Laura Robson, ed., Minorities and the Modern Arab World; Nelida Fuccaro, "Minorities and Ethnic Mobilisation. The Kurds in Northern Syria and Iraq", in The British and French Mandates in Comparative Perspectives, ed. Nadine Méouchy and Peter Sluglett (Leiden; Boston: Brill, 2004), 579-595; Nelida Fuccaro, The Other Kurds: Yazidis in Colonial Iraq (London: I.B. Tauris, 1999); Jordi Tejel, "The Monarchist Era Revisited", in Writing the Modern History of Iraq. Historiographical and Political Challenges, ed. Ricardo Bocco, Hamit Bozarslan, Peter Sluglett and Jordi Tejel (London: World Scientific, 2012), 87-94; Jordi Tejel, La question kurde. Passé et present (Paris: L'Harmattan), 2014; Heleen Murre-van den Berg, "Searching for Common Ground: Jews and Christians in the Modern Middle East", Laura Robson, 
"Refugee Camps and the Spatialization of Assyrian Nationalism in Iraq", and Helen MüllerSommerfeld, "The League of Nations, A-Mandates and Minority Rights during the Mandate Period in Iraq (1920-1932)", in Modernity, Minority, and the Public Sphere: Jews and Christians in the Middle East, eds. Goldstein-Sabbah, S. R, and H. L Murre-van den Berg (Leiden: Brill, 2016), 338; 237-57 and 258-283, Saba Mahmood, Religious Difference in the Secular Age: A Minority Report (Princeton, New Jersey: Princeton University Press, 2015).

${ }^{6}$ Paul S. Rowe, "Neo-millet Systems and Transnational Religious Movements: The Humayun Decrees and Church Construction in Egypt," Journal of Church and State 49, vol. 2 (2007): 329-50. ${ }^{7}$ Khaldun Ma'ruf, Al-Aqalliya al-yahudiyya fi al-'Iraq bayna sanat 1921 wa 1952 (Baghdad: Baghdad University, 1975).

${ }^{8}$ London, 20-22 December 1927 (BNA, CO 730/125/9). The results of his inquiry in Baghdad were published in Baghdad in a book titled The Constitutional Law of 'Iraq, Mackenzie and Mackenzie, 1928.

${ }^{9}$ Appendix to the letter by Nigel G. Davidson, Baghdad, to J.H. Thomas, Secretary of State for the Colonies, London, 24 July 1924 (BNA, T 161/158).

${ }^{10}$ I discuss these aspects in more details in Aline Schlaepfer, "Entre communauté et minorité juive. Les défis de la transition en Irak au moment de l'indépendance," in Minorités en Méditerranée aux XIXe et XXe siècles, eds Valérie Assan, Bernard Heyberger and Jakob Vogel, (Rennes : Presses universitaires de Rennes) (forthcoming 2018).

${ }^{11}$ L. Carl Brown, “The Setting: An Introduction”, in Imperial Legacy: The Ottoman Imprint on the Balkans and the Middle East, ed. L. Carl Brown (New York: Columbia University Press, 1996), $1-12$, here 8 .

12 Susan Pedersen, "Getting Out of Iraq — in 1932: The League of Nations and the Road to Normative Statehood", The American Historical Review 115, vol. 4 (2010): 975-1000, here 984. 
See also Susan Pedersen, The Guardians: The League of Nations and the Crisis of Empire (Oxford:

Oxford University Press, 2015).

13 "Memorandum on the League of Nations' Union and Guaranties for Minorities in Iraq", 8 December 1931 (BNA, CO 730/172/5).

${ }^{14}$ Helen Müller-Sommerfeld, "The League of Nations, A-Mandates and Minority Rights”, in Modernity, Minority, and the Public Sphere, ed. Goldstein, 258-283.

${ }^{15}$ Secret Report, Appendix A “The Jews of Iraq”, 9 July 1934 (BNA, AIR 23/806), in Records of Iraq, 1914-1966, ed. Alan de L. Rush, vol. 7 (Slough: Archives Ed., 2001), 630.

${ }^{16}$ Qanun al-ta'ifa al-isra'iliyya raqm 77, Bagdad, s. n., 1932.

${ }^{17}$ R. Brooke-Popham, Baghdad, to Colonial Secretary, London, 26 September 1930 (BNA, CO 730152 2). For more detailed analyzes of the relation between the Jewish community and Britain in Iraq, see Orit Bashkin, New Babylonians a History of Jews in Modern Iraq (Stanford: Stanford University Press, 2012); Aline Schlaepfer, Les intellectuels juifs de Bagdad. Discours et allégeances (1908-1951) (Leiden: Brill, 2016).

${ }^{18}$ J. Rich, London, to P. Azcaratè, Geneva, 9 December 1931 (LN, S345/2).

${ }^{19}$ Vivian Ibrahim, Review of Religious Difference in a Secular Age: A Minority Report by Saba Mahmood, The Middle East Journal 70, vol. 3 (2016): 507-508. 